\title{
Effect of Acute Treatment with Dimethylnitrosamine on the Contents of Cytochromes and on the Activities of $\delta$-Aminolevulinic Acid Synthetase, Heme Oxygenase and Drug-Metabolizing Enzymes in the Liver of Rats
}

\author{
(Received June 30, 1982) \\ Toshihiko ArIYoshi, Junko KaI, Satoko MitaraI, Takashi Nakashima \\ and Michiko WASHIZAKI \\ (Faculty of Pharmaceutical Sciences, Nagasaki University: 1-14 Bunkyo-machi, \\ Nagasaki-shi, Nagasaki, Japan)
}

The effects of acute treatment with dimethylnitrosamine (DMN) on the contents of cytochromes and on the activities of key enzymes in heme metabolic pathways were investigated in male Wistar rats.

Oral administration of DMN at a single dose of $30 \mathrm{mg} / \mathrm{kg}$ markedly decreased the contents of microsomal cytochrome P.450 and $b_{5}$, and this depression remained during 7 days after treatment. On the other hand, the activity of heme oxygenase was enhanced by $140 \%$ at 1 day, reached a peak (about $335 \%$ of the control) at 2 days, and returned to the initial level at 7 days after treatment. However, no significant change was observed in the activity of $\delta$-aminolevulinic acid synthetase throughout these experiments.

The activities of aminopyrine demethylase, aniline hydroxylase, bilirubin UDP-glucuronyltransferase, NADPH-cytochrome $c$ reductase and NADH-cytochrome $b_{5}$ reductase were all markedly reduced at 2 or 3 days after DMN treatment. In contrast, the activities of serum GPT and GOT and the content of serum bilirubin were significantly increased at 2 or 3 days after treatment.

In the case of phenobarbital pretreatment $(80 \mathrm{mg} / \mathrm{kg} /$ day for 3 days), no remarkable differences were seen in the activities of bilirubin UDP-glucuronyltransferase and of key enzymes in the heme metabolic pathways between groups given simultaneous treatment with phenobarbital and DMN and DMN treatment alone, although phenobarbital apparently potentiated the activities of serum GPT and GOT induced by DMN treatment.

Key words: dimethylnitrosamine; heme oxygenase; $\delta$-aminolevulinic acid synthetase; cytochrome P-450; cytochrome $b_{5}$; NADPH-cytochrome c reductase; NADH-cytochrome $b_{5}$ reductase; bilirubin UDP-glucuronyltransferase; serum bilirubin; serum transaminase

\section{Introduction}

Many workers have postulated that dimethylnitrosamine (DMN) is converted into toxic, carcinogenic and mutagenic intermediates by the cytochrome P.450 dependent mixed function oxidase system ${ }^{1) ~ 6)}$. However, some authors reported that the metabolism of DMN did not appear to be wholly mediated by cytochrome P.450 and DMN demethylase, and suggested that other enzyme systems may play an important role, because the cytochrome P-450 dependent mixed function oxidase involved in the metabolism of DMN was found to differ from some well established mixed function oxidases in its inducibility and susceptibility to inducers or inhibitors ${ }^{7) \sim 10)}$.

Although many studies have appeared on DMN demethylase ${ }^{11) ~ 20)}$, there is little information available concerning the influence of acute administration of DMN on the contents of chytochromes and on the activities of key 
enzymes which regulate the heme content in the heme metabolic pathways. Therefore, the purpose of this study was to determine the time course of the effects of DMN (single dose) on the contents of cytochrome P-450 and $b_{5}$ and on the activities of $\delta$-aminolevulinic acid (ALA) synthetase and heme oxygenase, which are the initial and rate-limiting enzymes in the biosynthesis and degradation of heme, respectively. In addition, we investigated whether any alteration occurred in the reaction sequence of microsomal electron transport systems or in the drugmetabolizing enzyme activities.

\section{Materials and Methods}

\section{Chemicals.}

Uridine-5'-diphosphoglucuronic acid trisodium salt was obtained from Nakarai Chemicals Ltd., Kyoto, Japan. Cytochrome c was purchased from Sigma Chemicals Co., St. Louis, Mo., USA. NADP, NADH, glucose 6-phosphate disodium salt and glucose 6-phosphate dehydrogenase were obtained from Boehringer Mannheim Yamanouchi Co., Ltd. Tokyo, Japan. Hemin, bilirubin and DMN were obtained from Tokyo Kasei Kogyo Co., Ltd., Tokyo, Japan. Other chemicals of reagent grade were obtained from commercial sources and used without further purification.

Animals.

Five-week-old male Wistar rats were pur- chased from Kyudo Co., Ltd., Tosu, Saga, Japan, and maintained on commercial rat chow (Clea CE-2, Nippon Clea Co., Ltd., Tokyo, Japan) and tap water ad libitum in the animal room for 1 week, then used for experiments.

Assay procedures.

Animals were given DMN orally at a single dose of $30 \mathrm{mg} / \mathrm{kg}$ in $0.9 \%$ saline solution at $5 \mathrm{ml}$ per $\mathrm{kg}$ by gastric intubation. Pretreatment of the animals involved intraperitoneal injections of phenobarbital $(\mathrm{PB}, 80 \mathrm{mg} / \mathrm{kg}$ in $0.9 \%$ saline solution at $2 \mathrm{ml}$ per $\mathrm{kg}$ ) at 72 , 48 and $24 \mathrm{hrs}$ before sacrifice. After treatment with DMN on schedule animals were sacrificed by decapitation; blood was collected for the determination of serum transaminase activities, and the livers were perfused in situ with cold $0.9 \%$ saline solution. The livers were removed and homogenized with 4 volumes of $0.25 M$ sucrose containing $1 \mathrm{mM}$ EDTA in a Potter-Elvehjem homogenizer with a Teflon pestle. Microsomes were prepared by the method described previously ${ }^{21)}$. Protein concentration was determined according to Lowry et al. ${ }^{22)}$ using bovine serum albumin as a standard. ALA synthetase activity of liver homogenates was determined by the method of Marver et $a l .^{23)}$. Heme oxygenase activity of microsomes was measured by the method of Maines and Kappas ${ }^{24)}$. Cytochrome P-450 and $b_{5}$ contents were estimated

Table 1. Effect of Dimethylnitrosamine on the Microsomal Cytochrome Contents and on the Activities of $\delta$-Aminolevulinic Acid Synthetase and Heme Oxygenase

\begin{tabular}{|c|c|c|c|c|c|c|}
\hline & \multirow[b]{2}{*}{$\begin{array}{l}\text { After } \\
\text { treatment } \\
\text { (d) }\end{array}$} & \multirow[b]{2}{*}{$\begin{array}{l}\text { Rat } \\
\text { No. }\end{array}$} & \multicolumn{2}{|c|}{ Cytochrome content ${ }^{a)}$} & \multicolumn{2}{|c|}{ Enzyme activity } \\
\hline & & & P.450 & $\mathrm{b}_{5}$ & $\begin{array}{c}\delta \text {-ALA } \\
\left.\text { synthetase }^{b}\right)\end{array}$ & $\begin{array}{c}\text { Heme } \\
\text { oxygenase }^{c}\end{array}$ \\
\hline Control & - & 8 & $0.90 \pm 0.04$ & $0.38 \pm 0.01$ & $35.8 \pm 2.8$ & $1.45 \pm 0.16$ \\
\hline Dimethyl. & 1 & 8 & $0.50 \pm 0.03^{* * * *}$ & $0.31 \pm 0.01^{* * * *}$ & $46.5 \pm 3.0$ & $2.06 \pm 0.17^{* *}$ \\
\hline nitrosamine & 2 & 8 & $0.45 \pm 0.02^{* * * *}$ & $0.23 \pm 0.01 * * * *$ & $31.9 \pm 1.5$ & $4.85 \pm 0.36^{* * * *}$ \\
\hline Control & - & 4 & $0.99 \pm 0.08$ & $0.36 \pm 0.01$ & $29.9 \pm 2.3$ & $1.44 \pm 0.18$ \\
\hline Dimethyl. & 3 & 4 & $0.56 \pm 0.04^{* * *}$ & $0.20 \pm 0.01 * * * *$ & $36.9 \pm 3.0$ & $3.04 \pm 0.43^{*}$ \\
\hline nitrosamine & 7 & 4 & $0.66 \pm 0.03 * * *$ & $0.28 \pm 0.02 * * *$ & $26.7 \pm 1.5$ & $1.47 \pm 0.7$ \\
\hline
\end{tabular}

Dimethylnitrosamine at a single dose of $30 \mathrm{mg} / \mathrm{kg}$ was administered to animals by gastric intubation, and animals were sacrificed $1,2,3$ or 7 days after the treatment with DMN. Each value represents the mean \pm S.E. of 4 to 8 rats. a): $\mathrm{nmol} / \mathrm{mg}$ protein; b): nmol $\delta$-ALA/g liver/hr; c): $\mathrm{nmol}$ bilirubin $/ \mathrm{mg}$ protein/hr. Significantly different from the corresponding mean of the control, $* \mathrm{P}<$ 0.05 , ** $\mathrm{P}<0.02$, *** $\mathrm{P}<0.01$ and **** $\mathrm{P}<0.001$. 
as described by Omura and Sato ${ }^{25)}$. Methods of determination of other enzyme activities were as follows-NADPH-chytochrome c reductase according to Omura and Takesue ${ }^{26)}$; NADH-cytochrome $b_{5}$ reductase according to Takesue and Omura ${ }^{27)}$; aminopyrine demethylase by means of the Nash reaction ${ }^{28)}$; aniline hydroxylase according to Imai et $a l .^{29)}$; glucuronyltransferase according to Heirwegh et $a l .{ }^{30)}$; glutamic oxaloacetic and glutamic pyruvic transaminase according to Reitman and Henkel $^{31}$.

\section{Results and Discussion}

The results of the time course experiments after single oral administration of $\mathrm{DMN}$ at a dose of $30 \mathrm{mg} / \mathrm{kg}$ on the contents of cytochrome P-450 and $b_{5}$ as well as on the activities of ALA synthetase and heme oxygenase are summarized in Table 1.

Numerous workers have reported that various chemicals, such as $\mathrm{PB}^{(7), 11), 15), 19), 35), 38), 41 \text {, }}$ 3-methylcholanthrene ${ }^{6), 7), 12), 15) ~ 17), 32,38), 41)}, \beta$ naphthoflavone ${ }^{6), 14), 38), 40)}$, pregnenolone-16 $\alpha$. carbonitrile ${ }^{(6), 34), 38), 40)}$, and so on ${ }^{13), 20), 33), 36) \sim 39) \text {. }}$ ${ }^{43)}$, and various factors ${ }^{18,35), 42)}$ affect the metabolism and hepatotoxicity of DMN. However, no detailed study has been reported of the effects on the contents of hepatic cytochromes and on the activities of enzymes of heme biosynthesis and degradation following acute intake of DMN. Smuckler et al.44) observed that DMN at a dose of $20 \mathrm{mg} / \mathrm{kg}$ led to a decrease in the amount of cytochrome P.450 at $2 \mathrm{hrs}$ after oral administration, and Skaare et $a l .^{39)}$ reported that DMN at a dose of $30 \mathrm{mg} / \mathrm{kg}$ caused a $42 \%$ decrease in cytochrome P. 450 concentration at $24 \mathrm{hrs}$ after intraperitoneal injection. However, Smuckler et al. ${ }^{44)}$ noted no difference in cytochrome $b_{5}$ content and Skaare et al. ${ }^{39)}$ did not report on cytochrome $b_{5}$ content after DMN treatment. In this study, we found that DMN produced maximum reduction in the cytochrome P. 450 content at 2 days but gave maximum reduction in the cytochrome $b_{5}$ content at 3 days after treatment. Subsequently, the contents of both cytochromes recovered somewhat, but were still low at 7 days after treatment $(67 \%$ and $78 \%$ of control levels, respectively). These findings suggest that such prolonged depression in the amount of cytochromes is due to loss of heme through an increase of heme degradation or a reduction of heme synthesis. Heme oxygenase activity was enhanced by $140 \%$ when meas-

Table 2. Effect of Dimethylnitrosamine on the Liver Constituents, Serum Bilirubin Content and on the Activities of Serum Transaminase and Hepatic Microsomal Enzymes

\begin{tabular}{lccc}
\hline & Control & \multicolumn{2}{c}{ DMN-treatment } \\
\cline { 3 - 3 } & & after 1d & after 2d \\
\hline Body weight initial $(\mathrm{g})$ & $123 \pm 4$ & $125 \pm 5$ & $126 \pm 4$ \\
final (g) & $141 \pm 5$ & $135 \pm 5$ & $133 \pm 5$ \\
Liver weight (g/100 g body weight) & $4.52 \pm 0.12$ & $4.44 \pm 0.14$ & $4.52 \pm 0.09$ \\
Liver glycogen (mg/g) & $65.3 \pm 4.5$ & $35.0 \pm 2.2^{* * * *}$ & $16.6 \pm 2.0^{* * * *}$ \\
Liver microsomal protein (mg/g) & $27.0 \pm 0.9$ & $23.7 \pm 1.0^{* *}$ & $21.8 \pm 1.1^{* * *}$ \\
Serum GOT (Karmen unit) & $88 \pm 2$ & $98 \pm 7$ & $151 \pm 10^{* * *}$ \\
Serum GPT (Karmen unit) & $43 \pm 5$ & $65 \pm 9$ & $138 \pm 15^{* * *}$ \\
Serum bilirubin (mg/100 ml) & $0.16 \pm 0.03$ & $0.21 \pm 0.01$ & $0.56 \pm 0.09^{* * *}$ \\
NADPH-cytochrome c reductase & $40.0 \pm 3.8$ & $36.4 \pm 2.1$ & $32.5 \pm 1.5$ \\
NADH-cytochrome b reductase & $2.21 \pm 0.11$ & $2.03 \pm 0.12$ & $1.77 \pm 0.06^{* *}$ \\
Aminopyrine demethylase & $4.26 \pm 0.26$ & $3.41 \pm 0.38$ & $2.16 \pm 0.25^{* * * *}$ \\
Aniline hydroxylase & $0.71 \pm 0.03$ & $0.42 \pm 0.02^{* * * *}$ & $0.44 \pm 0.02^{* * * *}$ \\
Bilirubin UDP-glucuronyltransferase & $18.9 \pm 1.1$ & $16.5 \pm 0.9$ & $14.3 \pm 0.5^{* * *}$
\end{tabular}

Dimethylnitrosamine (DMN, $30 \mathrm{mg} / \mathrm{kg}$, po) was administered to animals 1 or 2 days prior to sacrifice. Each value represents the mean \pm S.E. of 8 rats. ${ }^{a}{ }^{2}: \mathrm{nmol} / \mathrm{mg}$ protein $/ \mathrm{min} ;{ }^{\text {b) }}: \mu \mathrm{mol} / \mathrm{mg} \mathrm{pro}$ tein $/ \mathrm{min}$; ${ }^{\mathrm{c})}$ : $\mathrm{nmol}$ bilirubin conjugated $/ \mathrm{mg}$ protein $/ 10 \mathrm{~min}$. Significantly different from the corresponding mean of the control, ** $\mathrm{P}<0.02$, *** $\mathrm{P}<0.01$ or **** $\mathrm{P}<0.001$. 
Table 3. Effect of Dimethylnitrosamine on the Liver Constituents and the Activities of Serum Transaminase and Hepatic Microsomal Enzymes

\begin{tabular}{lccc}
\hline & & \multicolumn{2}{c}{ DMN-treatment } \\
\cline { 3 - 4 } & Control & after 3d & after 7d \\
\hline Body weight initial $(\mathrm{g})$ & $110 \pm 4$ & $108 \pm 2$ & $111 \pm 3$ \\
final (g) & $142 \pm 4$ & $134 \pm 5$ & $147 \pm 4$ \\
Liver weight (g/100 g body weight) & $5.07 \pm 0.03$ & $5.00 \pm 0.16$ & $5.25 \pm 0.20$ \\
Liver glycogen (mg/g) & $61.6 \pm 2.7$ & $29.7 \pm 8.8^{* *}$ & $53.8 \pm 7.6$ \\
Liver microsomal protein (mg/g) & $26.8 \pm 0.6$ & $22.3 \pm 0.4^{* * *}$ & $26.5 \pm 1.6$ \\
Serum GPT (Karmen unit) & $38 \pm 7$ & $84 \pm 9^{* * *}$ & $30 \pm 3$ \\
NADPH-cytochrome c reductase & $35.9 \pm 1.7$ & $25.4 \pm 1.9^{* * *}$ & $32.4 \pm 1.6$ \\
NADH-cytochrome $b_{5}$ reductase & $2.28 \pm 0.16$ & $1.55 \pm 0.10^{* * *}$ & $2.05 \pm 0.13$ \\
Aminopyrine demethylase & $3.44 \pm 0.16$ & $1.43 \pm 0.14^{* * *}$ & $2.28 \pm 0.28^{*}$ \\
Aniline hydroxylase & $0.79 \pm 0.06$ & $0.53 \pm 0.06^{*}$ & $0.72 \pm 0.08$ \\
Bilirubin UDP.glucuronyltransferase & $17.1 \pm 0.5$ & $12.3 \pm 0.9^{* * *}$ & $16.1 \pm 0.5$ \\
\hline
\end{tabular}

Dimethylnitrosamine (DMN, $30 \mathrm{mg} / \mathrm{kg}$, po) was administered to animals 3 or 7 days prior to sacrifice. Each value represents the mean \pm S.E. of 4 rats. ${ }^{\text {a) }}: \mathrm{nmol} / \mathrm{mg}$ protein $/ \mathrm{min}$; b): $\mu \mathrm{mol} / \mathrm{mg}$ protein/ $\mathrm{min} ;{ }^{c}$ : $\mathrm{nmol}$ bilirubin conjugated $/ \mathrm{mg}$ protein $/ 10 \mathrm{~min}$. Significantly different from the corresponding mean of the control, ${ }^{*} \mathrm{P}<0.05,{ }^{* *} \mathrm{P}<0.02$ or ${ }^{* * *} \mathrm{P}<0.01$.

ured 1 day after treatment with $\mathrm{DMN}$, reached a peak (about $335 \%$ of the control) at 2 days, and returned to the initial level at 7 days after treatment at the dose used, as shown in Table 1 . On the other hand, no significant alteration was observed in ALA synthetase activity throughout this experiment. Recently, many papers have demonstrated that heme or hemoprotein ${ }^{45)}$, heavy metals ${ }^{24), 46), 48)}$ and halogenated compounds ${ }^{47), 49)}$ markedly enhance the hepatic heme oxygenase activity and also accelerate the degradation of the heme moiety of cellular hemoprotein, cytochrome P-450. From these studies and our findings, we speculate that the enhancement of hepatic heme oxy. genase activity by acute intake of DMN is associated with the destruction of hemoprotein, cytochrome P.450 and $b_{5}$. However, it is uncertain whether the observed depression of hemoprotein is a direct cause of heme depletion, or a consequence of enhancement of heme oxygenase activity.

As shown in Tables 2 and 3 , the enzyme activities in the reaction sequence of microsomal electron transport systems, NADPHcytochrome c reductase and NADH-cytochrome $b_{5}$ reductase, were also appreciably dcreased at 2 or 3 days after DMN treatment. Maximum reduction in these enzyme activi- ties was seen at 3 days after treatment. However, this reduction seems noteworthy, because prolonged depressions in cytochrome contents and reductase activities in the reaction sequence of the microsomal electron transport system may to some extent induce the modification of cytochrome P.450 dependent mixed function oxidase, DMN demethylase, and DMN-mediated mutagenesis, even if the relationship between DMN demethylase activity and DMN-mediated mutagenesis is not linear ${ }^{19) .41)}$.

In addition, serum glutamic pyruvic transaminase (GPT) and glutamic oxaloacetic transaminase (GOT), which were measured as indicators of liver damage, were significantly enhanced at 2 or 3 days after DMN treatment. Maduagwu and Bassir ${ }^{42)}$ observed high values of serum GPT and GOT at 30 hrs after oral administration of DMN at a single dose of $50 \mathrm{mg} / \mathrm{kg}$. High values of serum transaminase indicate severe damage to liver cells. As shown in Table 2 or 3, DMN markedly decreased the contents of liver glycogen and microsomal protein, whereas it increased the content of serum bilirubin. Maduagwu and Bassiri2) also reported a marked increase of serum bilirubin in rats after administration of DMN at a single dose of $50 \mathrm{mg} / \mathrm{kg}$, or at a daily oral dose 
Table 4. Alterations of Dimethylnitrosamine Effect on the Hepatic Constituents and on the Activities of Serum and Hepatic Enzymes by Phenobarbital

\begin{tabular}{|c|c|c|c|c|}
\hline & Control & $\mathrm{PB}$ & $\mathrm{DMN}$ & $\mathrm{PB}+\mathrm{DMN}$ \\
\hline Body weight initial (g) & $94 \pm 3(3)$ & $92 \pm 3(3)$ & $93 \pm 6(4)$ & $91 \pm 3(4)$ \\
\hline final (g) & $119 \pm 3$ & $115 \pm 4$ & $115 \pm 2$ & $94 \pm 3^{*}$ \\
\hline Liver weight ( $\mathrm{g} / 100 \mathrm{~g}$ body weight) & $4.64 \pm 0.36$ & $5.33 \pm 0.13$ & $4.50 \pm 0.51$ & $5.71 \pm 0.28$ \\
\hline Liver glycogen $(\mathrm{mg} / \mathrm{g})$ & $65.5 \pm 1.0$ & $46.4 \pm 3.7^{* *}$ & $16.8 \pm 5.8^{* * *}$ & $19.5 \pm 1.0^{* * * *}$ \\
\hline Liver microsomal protein $(\mathrm{mg} / \mathrm{g})$ & 28. $1 \pm 1.9$ & $32.1 \pm 0.4$ & $20.6 \pm 0.1^{* * *}$ & $22.9 \pm 0.5^{*}$ \\
\hline Serum GOT (Karmen unit) & $89 \pm 9$ & $81 \pm 7$ & $269 \pm 48^{* *}$ & $450 \pm 56^{* * *}$ \\
\hline Serum GPT (Karmen unit) & $22 \pm 5$ & $20 \pm 3$ & $59 \pm 16^{*}$ & $157 \pm 18^{* * * *}$ \\
\hline NADPH-cytochrome $c$ reductase $\left.{ }^{a}\right)$ & $37.2 \pm 1.3$ & 59. $3 \pm 2.0 * * * *$ & $31.1 \pm 0.9^{*}$ & $47.1 \pm 0.9^{* * *}$ \\
\hline NADH-cytochrome $b_{5}$ reductase $\left.{ }^{b}\right)$ & $2.52 \pm 0.13$ & $2.67 \pm 0.12$ & $1.78 \pm 0.01^{* *}$ & $1.64 \pm 0.06^{* * *}$ \\
\hline Cytochrome P-450') & $0.86 \pm 0.07$ & $1.87 \pm 0.14^{* * *}$ & $0.45 \pm 0.08^{* * *}$ & $1.02 \pm 0.07$ \\
\hline Cytochrome $b_{5}{ }^{c)}$ & $0.36 \pm 0.03$ & $0.49 \pm 0.02 * *$ & $0.21 \pm 0.01^{* * *}$ & $0.31 \pm 0.01$ \\
\hline Aminopyrine demethylase ${ }^{a}$ ) & $3.35 \pm 0.33$ & $8.71 \pm 0.68 * * *$ & $2.20 \pm 0.25^{*}$ & $6.34 \pm 0.46^{* * *}$ \\
\hline Aniline hydroxylase ${ }^{\text {a }}$ & $0.72 \pm 0.08$ & $1.42 \pm 0.05^{* * *}$ & $0.38 \pm 0.05^{*}$ & $0.78 \pm 0.08$ \\
\hline Bilirubin UDP-glucuronyltransferase $\left.{ }^{d}\right)$ & $18.7 \pm 0.6$ & $19.6 \pm 2.1$ & $13.5 \pm 1.8^{* *}$ & $14.3 \pm 0.9 * * *$ \\
\hline$\delta$-ALA synthetase ${ }^{\theta)}$ & $37.0 \pm 4.7$ & $25.3 \pm 1.4$ & $30.6 \pm 2.1$ & $35.0 \pm 3.8$ \\
\hline Heme oxygenase ${ }^{f)}$ & $1.74 \pm 0.16$ & $1.09 \pm 0.02 * *$ & $3.84 \pm 0.13^{* *}$ & $4.03 \pm 0.17 * *$ \\
\hline
\end{tabular}

Phenobarbital (PB, $80 \mathrm{mg} / \mathrm{kg}$, ip) pretreated to rats daily for 3 days, and at 4 th day animals were given a single dose of dimethylintrosamine (DMN, $30 \mathrm{mg} / \mathrm{kg}$, po) and then sacrified $48 \mathrm{hr}$ after DMN treatment. Each value represents the mean \pm S.E. of 3 to 4 rats. ${ }^{\text {a) }}$ : $\mathrm{nmol} / \mathrm{mg}$ protein $/ \mathrm{min}$; b): $\mu \mathrm{mol} / \mathrm{mg}$ protein/min; ${ }^{c)}: \mathrm{nmol} / \mathrm{mg}$ protein; ${ }^{\mathrm{d})}: \mathrm{nmol}$ bilirubin conjugated $/ \mathrm{mg}$ protein $/ 10 \mathrm{~min}$; ${ }^{\ominus)}$ : nmol $\delta$-ALA/g liver/hr; ${ }^{\mathrm{f}}$ ): $\mathrm{nmol}$ bilirubin/mg protein/hr. Significantly different from the corresponding mean of the control, $* \mathrm{P}<0.05, * * \mathrm{P}<0.02, * * * \mathrm{P}<0.01$ or $* * * * \mathrm{P}<0.001$.

of $5 \mathrm{mg} / \mathrm{kg}$ for 5 to 11 days or of $1 \mathrm{mg} / \mathrm{kg}$ for 30 days. They suggested that the high values of serum bilirubin might be due to intrahepatic cell damage. In this study, we observed that the single administration of DMN produced considerable depression of bilirubin UDP-glucuronyltransferase in the phase II reaction as well as of aminopyrine demethylase and aniline hydroxylase in the phase I reaction. These findings also suggest that acute intake of DMN may alter the metabolism of DMN itself and enhance DMNmediated toxicity or mutagenicity. Furthermore, the depression of UDP-glucuronyltransferase activity for bilirubin would lead to an increase in the amount of unconjugated bilirubin in serum with an increase of heme oxygenase activity as shown in Table 1 . This would appear to present a serious risk of hyperbilirubinemia to the fetus and newborn as a result of direct or maternal acute intake of DMN.

Table 4 shows the influence of $\mathrm{PB}$ pretreatment on the above effects of DMN. Some ivestigators reported that PB modified DMN demethylase or the rate of metabolism of $\mathrm{DMN}^{(7), 11,(15), 19), 35), 38), 41)}$. In this study, $\mathrm{PB}$ partially enhanced the toxic effects of DMN, namely concomitant treatment with $\mathrm{PB}$ and $\mathrm{DMN}$ significantly reduced the average body weight gains by rats and potentiated the enhanced activities of serum GPT and GOT induced by $\mathrm{DMN}$ as compared to the activities in animals treated with DMN alone. However, no significant differences were seen in the activities of key enzymes of the heme metabolic pathways, of bilirubin UDP-glucuronyltransferase or of NADH-cytochrome $b_{5}$ reductase between groups given simutaneous treatment with $\mathrm{PB}$ and DMN and DMN treatment alone. Interestingly, $\mathrm{PB}$ reduced the activity of heme oxygenase compared to the control. This may suggest an increase of heme content in the hepatic heme pool in vivo. Striking differences in the contents of cytochromes and in the activities of aminopyrine demethylase, aniline hydroxylase and NADPH-chytochrome c reductase were apparent between combined treatment with $\mathrm{PB}$ and DMN and DMN treatment alone. On 
the other hand, the cytochrome contents and enzyme activities in the case of simultaneous administration of $\mathrm{PB}$ and $\mathrm{DMN}$ were similar to or slightly larger than those of non-treated controls, as shown in Table 4. It is toxicologically important that DMN demethylase activities, as well as the rate of metabolism of DMN and its biological effects in living animals, are susceptible to modification by various environmental chemicals and factors, as has been demonstrated in many studies.

Various biological effects of DMN at chronic and very low dose levels are being investigated and further study on the interaction effects of DMN with common chemicals, such as alcohol, tobacco smoke constituents and essential metals, is required.

\section{References}

1) Magee, P. N., Vandekar, M.: Biochem. J., 70, $600 \sim 605$ (1958).

2) Czygan, P., Greim, H., Garro, A. J., Hutterer, F., Schaffner, F., Popper, H., Rosental, O., Cooper, D. Y.: Cancer Res., 33, 2983 2986 (1973).

3) Lotlikar, P. D., Baldy, W. J. Jr., Dwyer, E. N.: Biochem. J. 152, 705 708 (1975).

4) Guengerich, F. P.: J. Biol. Chem., 252, 3970 3979 (1977).

5) Argus, M. F., Arcos, J. C., Pastor, K. M., Wu, B. C., Venkatesan, N.: Chem.-Biol. Interact., 13, 127 140 (1976).

6) Lai, D. Y., Myers, S. C., Woo, Y. T., Greene, E. J., Friedman, M. A., Argus, M. F., Arcos, J. C.: ibid., 28, 107 126 (1979).

7) Phillips, J. C., Heading, C. E., Lake, B. G., Gangolli, S. D., Lloyd, A. G.: Fd. Cosmet. Toxicol., 13, 611 617 (1975).

8) Lake, B. G., Phillips, J. C., Heading, C. E., Gangolli, S. D.: Toxicology, 5, 297 309 (1976).

9) Godoy, H. M., Diaz Gomez, M. I., Castro, J. A.: J. Nat. Cancer Inst., 61, 1285 1289 (1978).

10) Kroeger-Koepke, M. B., Michejda, C. J.: Cancer Res., 39, 1587 1591 (1979).

11) Arcos, J. C., Davies, D. L., Brown, C. E. L., Argus, M. F.: Z. Krebsforsch., 89, 181 199 (1977).

12) Lotlikar, P. D., Hong, Y. S., Baldy, W. J. Jr.: Cancer Lett., 4, 355 361 (1978).

13) Sipes, I. G., Slocumb, M. L., Holtzman, G.: Chem.-Biol. Interact., 21, 155 166 (1978).

14) Lai, D. Y., Arcos, J. C.: Life Sci., 27, 2149 2165 (1980).
15) Kato, R., Shoji, H., Takanaka, A.: Gann, 58, 467 469 (1967).

16) Venkatesan, N., Arcos, J. C., Argus, M. F.: Life Sci., 7, 1111 1119 (1968).

17) Venkatesan, N., Argus, M. F., Arcos, J. C.: Cancer Res., 30, 2556 2562 (1970).

18) Venkatesan, N., Arcos, J. C., Argus, M. F.: ibid., 30, 2563 2567 (1970).

19) Guttenplan, J. B., Hutterer, F., Garro, A. J.: Mutat. Res., 35, 415 422 (1976).

20) Guttenplan, J. B., Garro, A. J.: Cancer Res., 37, 329 330 (1977).

21) Ariyoshi, T., Takabatake, E., Remmer, H.: Life Sci., 9, Part II, 361 369 (1970).

22) Lowry, O. H., Rosebrough, N. J., Farr, A. L., Randall, R. J.: J. Biol. Chem., 193, 265 275 (1951).

23) Marver, H. S., Tschudy, D. P., Perloth, M. G., Collins, A.: ibid., 241, 2803 2809 (1966).

24) Maines, M. D., Kappas, A.: Biochem. J., 154, 125 131 (1976).

25) Omura, T., Sato, R.: J. Biol. Chem., 239, $2370 \sim 2378$ (1964).

26) Omura, T., Takesue, S.: J. Biochem. (Tokyo), 67, 249 257 (1970).

27) Takesue, S., Omura, T.: ibid., 67, 267 276 (1970).

28) Nash, T.: Biochem. J., 55, 416 421 (1953).

29) Imai, Y., Ito, A., Sato, R.: J. Biochem.(Tokyo), 60, 417 428 (1966).

30) Heirwegh, K. P. M., Van De Vijver, M., Fevery, J.: Biochem. J., 129, 605 618 (1972).

31) Reitman, S., Frankel, S.: Am. J. Clin. Pathol., 28, 56 63 (1957).

32) Hoch-Ligeti, C., Argus, M. F., Arcos, J. C.: J. Nat. Cancer Inst., 40, 535 549 (1968).

33) Fiume, L., Campadelli-Fiume, G., Magee, $P$. N., Holsman, J.: Biochem. J., 120, 601 605 (1970).

34) Somogyi, A., Conney, A. H., Kuntzman, R.: Nature (London), New Biol., 237, 61 63 (1972).

35) McLean, A. E. M., Day, P. A.: Biochem. Pharmacol., 23, 1173 1180 (1974).

36) Maling, H. M., Highman, B., Williams, M. A., Saul, W., Butler, W. M., Jr., Brodie, B. B.: Toxicol. Appl. Pharmacol., 27, 380 394 (1974).

37) Maling, H. M., Stripp, B., Sipes, I. G., Highman, B., Saul, W., Williams, M. A.: ibid., 33, $291 \sim 308$ (1975).

38) Arcos, J. C., Bryant, G. M., Venkatesan, N., Argus. M. F.: Biochem. Pharmacol.. 24, 1544 1547 (1975).

39) Skaare, J. U., Nafstad, I., Dahle, H. K.: Toxicol. Appl. Pharmacol., 42, 19 31 (1977).

40) Argus, M. F., Hoch-Ligeti, C., Arcos, J. C., 
Conney, A. H.: J. Nat. Cancer Inst., 61, 441 449 (1978).

41) Hutton, J. J., Meier, J., Hackney, C.: Mutat. Res., 66, 75 94 (1979).

42) Maduagwu, E. N., Bassir, O.: Toxicol. Appl. Pharmacol., 53, 211 219 (1980).

43) Garro, A. J., Seitz, H. K., Lieber, C. S.: Cancer Res., 41, 120 124 (1981).

44) Smuckler, E. A., Arrhenius, E., Hultin, T.: Biochem. J., 103, 55 64 (1967).

45) Bissell, D. M., Hammaker, L. E.: Arch. Bio- chem. Biophys., 176, 91 102 (1976).

46) Drummond, G. S., Kappas, A.: Proc. Nat. Acad. Sci. U. S. A., 76, 5331 5335 (1979).

47) Guzelian, P. S., Elshourbagy, N. A.: Arch. Biochem. Biophys., 196, 178 185 (1979).

48) Rosenberg, D. W., Drummond, G.S., Cornish, H. C., Kappas, A.: Biochem. J., 190, 465 468 (1980).

49) Ariyoshi, T., Eguchi, M., Muraki, Y., Yasumatsu, H., Suetsugu, N., Arizono, K.: J. Pharm. Dyn., 4, 69 76 (1981). 